\title{
PENGGUNAAN EMOJI $:$ UNTUK MENINGKATKAN PERILAKU BAIK (WELL-BEING) DAN KEMAMPUAN BAHASA ANAK USIA DINI
}

\author{
Waode Eti Hardiyanti ${ }^{1}$, Muhammad Ilham², Aris Suziman ${ }^{3,}$ Astriyani $^{4}$ \\ ${ }^{1}$ Universitas Negeri Gorontalo \\ ${ }^{2}$ IAIN Kendari \\ ${ }^{3,4}$ Universitas Sulawesi Tenggara \\ Email : waode@ung.ac.id, muhammadilham@iainkendari.ac.id, \\ astriyanikendari@gmail.com
}

\begin{abstract}
ABSTRAK
Penelitian ini bertujuan untuk meningkatkan perilaku baik (well-being) dan kemampuan bahasa anak usia dini melalui penggunaan emoji sebagai media pembelajaran. Gambar emoji yang digunakan terdiri dari emoji wajah, objek dan aktivitas yang mudah dipahami anak serta berkaitan dengan pengalaman seharihari mereka. Teknik pengumpulan data menggunakan lembar observasi untuk mengukur well-being dan kemampuan bahasa serta observasi langsung yang dilakukan peneliti. Penelitian ini menggunakan metode deskriptif kualitatif dengan sampel berjumlah 25 anak, usia antara 5-6 tahun disalah satu PAUD di Konawe Selatan. Hasil penelitian ini menemukan bahwa media emoji secara positif dapat meningkatkan perilaku baik dan kemampuan bahasa anak. Anak selalu menunjukkan ketertarikan saat menirukan, mendefinisikan, menjelaskan dan menghubungkan emoji dengan objek dan perasaan yang mereka alami. Anak menceritakan pengalaman sehari-hari yang berhubungan dengan emoji, sehingga mereka menjadi pusat dari kegiatan belajar dimana pendapat dan ide mereka sangat didengar dan dihargai, yang merupakan indikator penting untuk meningkatkan perilaku baik anak. Sifat emoji yang terbuka membuat anak mendapat kesempatan untuk mendiskusikan simbol emoji yang tepat menurut mereka juga membantu peneliti untuk dapat memahami cara anak memaknai dunia mereka sendiri. Adapun, aspekaspek kemampuan berbahasa anak yang ditingkatkan selama kegiatan ini berupa kosakata, kemampuan anak dalam memberikan definisi, solusi dan contoh dari situasi tertentu, dan kepercayaan diri..
\end{abstract}

Kata Kunci: perilaku baik anak; emoji; kemampuan bahasa; PAUD

\begin{abstract}
This study aims to improve children's well-being and communication skills using emoji as a learning media. Emoji images used consist of facial emojis, objects and activities that are easily understood and close to children's daily experiences. The techniques of collecting data were observation sheet and direct observation by researchers. This study used a qualitative descriptive method and the samples were 25 children, collected through purposive sampling, aged between 5-6 years in one PAUD in Konawe Selatan. The results of this study found that emoji media can positively improve children's well-being and their language abilities. Children always showed huge interest when imitating, affirming, explaining and connecting emojis with objects and their feelings. Children told their daily experiences associated with emojis, hence they become the center of learning where their opinion and ideas are truly heard and understood, which is an important indicator to improve children's well-being. The open-ended nature of
\end{abstract}


Waode Eti Hardiyanti, Muhammad Ilham, Aris Suziman, Astriyani

PENGGUNAAN EMOJI $\ddot{\bullet}$ UNTUK MENINGKATKAN PERILAKU BAIK (WELLBEING) DAN KEMAMPUAN BAHASA ANAK USIA DINI

Early Childhood: Jurnal Pendidikan. Vol. 3 No. 2., November 2019

emojis makes children have the opportunity to discuss emoji symbols that are correct according to them and also help researchers interpret how children see their own world. Meanwhile, language ability aspects increased during this activity were vocabulary, the children ability to provide definition, solutions and examples of certain problems, and self-confidence.

Keywords: children well-being; emoji; communication skill; preschools

\section{PENDAHULUAN}

Perilaku well-being dan kemampuan bahasa anak adalah dua hal penting yang menjadi fokus Pendidikan Anak Usia Dini (PAUD) sesuai kurikulum 2013 (Pendidikan \& Kebudayaan, 2017). Well-being dalam konteks ini diartikan sebagai keadaan untuk mengidentifikasikan area yang diperlukan untuk mendukung perkembangan kesehatan mental dan perilaku serta sikap anak (Fane, MacDougall, Redmond, Jovanovic, \& Ward, 2016). Kesehatan mental dan perilaku anak sangat sering dipengaruhi oleh berbagai faktor di antaranya penggunaan teknologi yang masif, fokus yang berlebihan terhadap kemampuan kognitif dan maraknya pemberian label pada anak, seperti "anak pintar vs anak lambat" atau "anak nakal vs anak rajin". United Nations Internasional Children's Emergency Fund (UNICEF, 2013) menjelaskan bahwa anak memiliki hak untuk mengatakan apa yang harus dilakukan dan untuk mendengarkan pendapat mereka diperlukan berbagai ide untuk mengakomodasikannya baik melalui lisan, tulisan, dalam media cetak, dalam bentuk seni, dan melalui media pilihan anak lainnya. Mengakomodasi pendapat dan ide anak menunjukkan bahwa anak dianggap sebagai individu yang berpengetahuan dan mampu berkontribusi dalam kegiatan hari-hari mereka (Fane, 2017).

Sementara itu, kemampuan bahasa anak sangat dipengaruhi oleh rangsangan yang diterima dan lingkungan yang memberikan kesempatan bagi anak untuk mengembangkan komunikasi. Pendidikan Anak Usia Dini (PAUD) mengalami perkembangan yang pesat dan fundamental pada masa ini (Delfita 2012). Kematangan bahasa dan konteks bermain sangat bergantung pada proses perkembangan dan frekuensi paparan bahasa yang didapat anak. Kemampuan bahasa anak juga penting untuk mengekspresikan perkembangan sosialemosional anak baik secara verbal dan non-verbal. Dalam proses pengembangan bahasa, anak mengekspresikan pikiran, perasaan dan keinginannya untuk menyampaikan makna bagi pendengarnya.

Guna mewujudkan peningkatan well-being dan kemampuan berbicara anak, penggunaan media yang menarik dan sesuai dengan usia anak adalah penting. Penggunaan emoji atau ekspresi yang berbentuk komunikasi 
Waode Eti Hardiyanti, Muhammad Ilham, Aris Suziman, Astriyani

PENGGUNAAN EMOJI $\ddot{\theta}$ UNTUK MENINGKATKAN PERILAKU BAIK (WELLBEING) DAN KEMAMPUAN BAHASA ANAK USIA DINI

Early Childhood: Jurnal Pendidikan. Vol. 3 No. 2., November 2019

dalam bentuk tekstual dapat menjadi media kreatif dan inovatif dalam berkomunikasi dan meningkatkan kesadaran well-being anak (Fane et al. 2016; Kelly \& Watts, 2015; Suwarti, Akmal, \& Sodiq, 2016) Penelitian yang di lakukan Fane (2017) melibatkan 78 anak usia 3-5 tahun, menggunakan emoji sebagai media visual untuk mendengarkan, mengeksplorasi, dan membagi pendapat mereka mengenai sifat dan perilaku yang dimunculkan pada emoji tersebut. Penggunaan emoji terbukti dapat meningkatkan pemahaman anak mengenai well-being, sebab emoji dapat diartikan lebih dari satu makna sehingga anak perlu untuk membangun makna dan mendiskusikannya bersama dengan teman sebayanya.

Perumusan Masalah

1) Bagaimana media emoji dapat meningkatkan well-being anak di PAUD?

2) Bagaimanakah potensi media emoji untuk meningkatkan kemampuan bahasa anak di PAUD?

\section{Tujuan Penelitian}

Penelitian ini bertujuan untuk meningkatkan well-being anak dan kemampuan bahasa melalui media gambar emoji guna meningkatkan kreativitas pengajaran bagi anak usia dini.

\section{Pengertian Emoji}

Penggunaan teknologi dan media baik berupa tulisan maupun simbol semakin meningkat. Hal ini pula terjadi di kehidupan sehari-hari anak yang tidak asing lagi dengan teknologi (iPad, Smartphone, Tv) yang berfungsi sebagai sumber informasi dan komunikasi. Komunikasi visual erat kaitannya dengan penggunaan emoji yang berasal dari Jepang sebagai simbol grafis guna mengekspresikan berbagai ide dan konsep yang umumnya digunakan pada dalam komunikasi seluler dan media sosial (Novak, Smailović, Sluban, \& Mozetič, 2015) Emoji awalnya berasal dari emoticon, yaitu bentuk sederhana dari ekspresi wajah yang dapat dibuat melalui keyboard misalnya :-). Kemudian berkembang menjadi berbagai macam ekspresi baik berupa ekspresi wajah manusia, perasaan, gerak tubuh, benda, hewan, makanan dan minuman, dan aktivitas.

Penggunaan emoji pada anak usia dini selaras dengan konsep multiliterasi yang tidak hanya berfokus pada konsep tradisional membaca, menulis, berbicara, dan mendengarkan namun juga termasuk simbol, logo dan sistem tanda baca (Fane, 2017). Meskipun penggunaan emoji tergolong relatif baru namun karena meningkatnya penggunaan teknologi sebagai alat komunikasi dan informasi mendorong penggunaan simbol ini tak 
Waode Eti Hardiyanti, Muhammad Ilham, Aris Suziman, Astriyani

PENGGUNAAN EMOJI $\ddot{\theta}$ UNTUK MENINGKATKAN PERILAKU BAIK (WELLBEING) DAN KEMAMPUAN BAHASA ANAK USIA DINI

Early Childhood: Jurnal Pendidikan. Vol. 3 No. 2., November 2019

dapat terlepas dari kehidupan seharihari.

Pentingnya Meningkatkan Well-being dan Kemampuan Bahasa Anak

Pengertian well-being sering kali dihubungkan dengan faktor kesehatan dan kesejahteraan. Namun dalam konteks pendidikan anak usia dini, mengenali kebutuhan dan dukungan kepada perkembangan emosi anak merupakan fokus yang ingin dicapai (Fane, 2017). Dukungan yang dilakukan oleh pendidik anak usia dini dapat dilakukan dalam bentuk hubungan positif anak dan guru. Guru perlu untuk merespons pada kelebihan anak, ketertarikan dan kemampuan serta pengalaman anak di komunitasnya. Saat anak mendapatkan dukungan tersebut, mereka akan merasa dihargai dalam mengutarakan pendapat dan idenya. Hal ini akan meningkatkan perkembangan kepercayaan diri dan kemampuan anak untuk bertindak mandiri dalam kesehariannya dan untuk meningkatkan hubungan sosial dengan orang lain.

Selain well-being anak, kemampuan bahasa menjadi sangat penting dalam perkembangan anak. Menurut Bawono (2017) bahasa didefinisikan sebagai alat komunikasi yang digunakan untuk menyampaikan maksud, pendapat, gagasan dan ide baik berupa verbal dan tulisan. Perkembangan bahasa pada anak usia dini berkembang sangat pesat dan penting guna mendukung berbagai perkembangan seperti kognitif, sosial dan emosional.

$\begin{array}{llr}\text { Penggunaan } & \text { Emoji } & \text { dalam } \\ \text { Meningkatkan } & \text { Well-being } & \text { dan } \\ \text { Kemampuan Bahasa Anak } & \end{array}$
Emoji yang umumnya digunakan untuk menyampaikan makna dan pendapat dapat memberikan kesempatan kepada anak secara bebas untuk pendapat dan ide mereka. Selain itu, anak akan mengenali perilaku sikap dan perilaku anak itu sendiri. Emoji juga dapat digunakan untuk mendeskripsikan kegiatan mereka di sekolah dan rumah serta menjelaskan pengalaman anak yang melibatkan emoji tersebut. Penggunaan emoji dalam konteks pendidikan sangat mendukung anak-anak dalam mengeksplorasi dan mengekspresikan pemahaman mereka tentang well-being (Fane, 2017). Alasannya adalah karena sifat emoji yang terbuka membuat anak mendapat kesempatan untuk mendiskusikan simbol emoji yang tepat menurut mereka juga membantu guru untuk dapat memahami cara anak memaknai dunia mereka sendiri.

Penggunaan emoji sebagai alat untuk melibatkan anak-anak dalam mengembangkan pemahaman dan komunikasi mereka. Alat komunikasi ini dapat membantu anak untuk mengartikan ekspresi yang pada emoji kemudian menyampaikan pengalamannya saat berada di keadaan yang sama. Dengan menggunakan emoji, pembelajaran bahasa akan 
Waode Eti Hardiyanti, Muhammad Ilham, Aris Suziman, Astriyani

PENGGUNAAN EMOJI $\ddot{\ominus}$ UNTUK MENINGKATKAN PERILAKU BAIK (WELLBEING) DAN KEMAMPUAN BAHASA ANAK USIA DINI

Early Childhood: Jurnal Pendidikan. Vol. 3 No. 2., November 2019

semakin menarik karena anak dapat memilih berbagai ekspresi yang ingin ditampilkan dan menceritakan alasan memilih gambar tersebut ( Suwarti, Akmal, \& Sodiq, 2016).

\section{METODE PENELITIAN}

Penelitian ini menggunakan metode deskriptif kualitatif. Penelitian ini dilakukan oleh tiga orang pengusul selama tiga bulan di PAUD Al-FIKR, yang berjumlah 25 anak dengan usia antara 5-6 tahun.

Tahap Pelaksanaan:

a). Perencanaan

1. Membuat skenario pembelajaran berupa rencana kegiatan harian ( $\mathrm{RKH})$ untuk pertemuan I sampai dengan pertemuan IV untuk mendukung peningkatan kemampuan well-being dan bahasa anak.

2. Menyiapkan kartu dan stiker emoji atau media pembelajaran yang diperbesar menjadi $10 \mathrm{~cm}$ x $10 \mathrm{~cm}$, sebanyak 40 gambar yang dilaminating.

3. Membuat lembar observasi aktivitas anak didik selama proses belajar dalam kegiatan untuk meningkatkan wellbeing anak dan bahasa.

b). Pelaksanaan tindakan

Pada tahap ini meliputi pelaksaan tindakan yang dilakukan oleh peneliti/guru sedangkan guru kelas sebagai pengamat. Adapun pelaksanaan tindakan meliputi:

1. Peneliti memulai dengan memperlihatkan emoji yang mewakili perasaan dan ekspresi wajah yang berbeda kepada anak (emoji 1-5 di gambar 1).

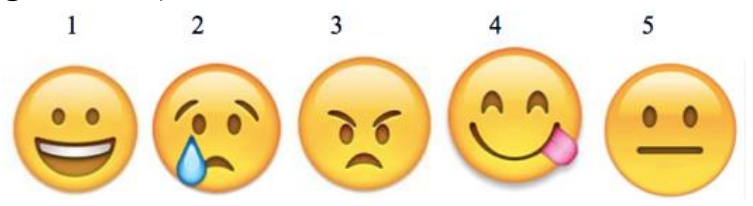

Gambar 1 Emoji ekspresi wajah

2. Anak-anak pertama kali diminta untuk mengidentifikasi perasaan atau emosi yang digambarkan oleh gambar wajah. Selanjutnya, anak-anak diminta untuk memilih salah satu emoji, dan menceritakan kisah tentang mengapa seseorang mungkin merasakan perasaaan tersebut.

3. Setelah para peserta berbagi semua ide yang mereka inginkan dengan peneliti, peneliti membentuk kelompok kecil (3-5 anak), kemudian peneliti memberikan masing-masing kelompok gambar emoji, yang terdiri dari 7 emoji wajah dan 3 emoji objek yang dipilih untuk mewakili objek umum, lingkungan, aktivitas, atau simbol yang anak-anak kenal (emoji 6-10 di gambar 2).

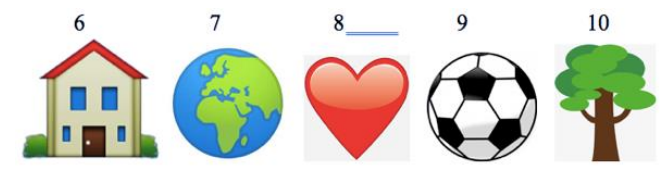

Gambar 2 Emoji objek dan aktivitas

4. Setelah para peserta berkesempatan untuk mengeksplorasi emoji baru, mereka diminta untuk memilih satu dan menceritakan sebuah kisah tentangnya. Peneliti terlibat dengan setiap tanggapan anak-anak di seluruh kelompok, mengajukan pertanyaan klarifikasi jika tanggapan tidak 
Waode Eti Hardiyanti, Muhammad Ilham, Aris Suziman. Astriyani

PENGGUNAAN EMOJI $\ddot{\theta}$ UNTUK MENINGKATKAN PERILAKU BAIK (WELLBEING) DAN KEMAMPUAN BAHASA ANAK USIA DINI

Early Childhood: Jurnal Pendidikan. Vol. 3 No. 2., November 2019

dipahami oleh peneliti, dan mengulang kembali ide atau cerita anak untuk memastikan peneliti telah memahami dengan benar.

5. Kegiatan ini berlangsung selama 4 pertemuan guna melihat peningkatan keaktifan anak, emoji yang digunakan pun dapat berbeda ataupun tetap sama di setiap pertemuan. Pada pertemuan berikutnya, peneliti mengenalkan emoji menggunakan komputer/laptop dan Smarthphone dalam konteks komunikasi. Hal ini bertujuan untuk mengenalkan penggunaan emoji dalam bentuk kontekstual.

\section{c). Observasi/pengamatan}

Pada tahap ini dilaksanakan pengamatan secara saksama mengenai aktivitas anak didik selama mengikuti proses pembelajaran. Observasi dilakukan juga terhadap guru untuk melihat sejauh mana keterlibatan dan keaktifan anak dalam proses pembelajaran menggunakan emoji guna meningkatkan kemampuan bahasa dan well-being seperti dalam lampiran 1.

Analisis Data

Penelitian ini menggunakan konten analisis di mana setiap isi atau informasi yang terjadi di dalam kelas selama diskusi dicatat dan dikelompokkan berdasarkan tema yang sesuai. Kemudian, tema yang muncul dihubungkan dengan teori yang mengenai well-being anak dan perkembangan

\section{HASIL DAN PEMBAHASAN}

Hasil dan pembahasan yang menjadi fokus dalam penelitian ini terbagi atas dua capaian yaitu perilaku baik (wellbeing) dan kemampuan bahasa anak. Perilaku baik anak (children's wellbeing)

Anak yang menjadi objek dalam kegiatan ini, secara umum menunjukkan ketertarikan yang sangat besar terhadap penggunaan emoji sebagai media pembelajaran di kelas. Sebagian besar anak merasa penasaran dengan gambar yang diperlihatkan, dan sebagian lainnya merasa familier dengan gambar tersebut karena pernah melihat baik pada video di Youtube, sampul buku, dan iklan di TV. Seperti yang tercermin dari diskusi di bawah ini:

Pertemuan 1 (kelompok 1)

Peneliti : [berbicara di depan kelas sambil memegang beberapa gambar emoji] Anak-anak ada yang tahu gambar yang ibu pegang ini apa

$$
\text { ya? }
$$

Anak 1 : Itu gambar seperti yang saya dilihat di HP [video dari YouTube] warna kuning.

Anak $2 \quad:$ Bu, saya pernah lihat di bukunya kakakku, kayak lingkaran dan macam-macam gambarnya.

Peneliti : Iya, benar sekali yang disebutkan. Ini namanya emoji yang gambarnya ada banyak ekspresi, seperti senang, sedih, marah, dan kaget.

Peneliti :[peneliti menunjukkan gambar emoji tertawa terbahak-bahak] ini gambar emoji apa yah? 
Waode Eti Hardiyanti, Muhammad Ilham, Aris Suziman, Astriyani

PENGGUNAAN EMOJI $\ddot{\ominus}$ UNTUK MENINGKATKAN PERILAKU BAIK (WELLBEING) DAN KEMAMPUAN BAHASA ANAK USIA DINI

Early Childhood: Jurnal Pendidikan. Vol. 3 No. 2., November 2019

Anak-anak : [spontan memperagakan gambar emoji yang ditunjukkan oleh peneliti (gambar 3)]

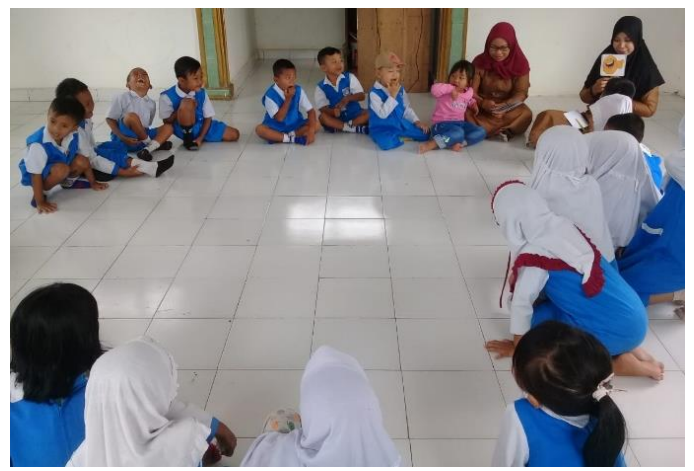

Gambar 3. Sebagian anak secara spontan menirukan ekspresi wajah emoji

Dari hasil observasi, diskusi yang dilakukan anak dan peneliti, dan gambar di atas menunjukkan ketertarikan besar anak pada media pembelajaran emoji. Hal ini mengaitkan rasa ingin tahu anak terhadap gambar emoji, yang selama ini tidak pernah digunakan sebagai media di sekolah tersebut. Disisi lain, gambar emoji semakin sering digunakan dalam percakapan secara umum dan banyak digunakan pada media elektronik (HP dan TV). Sehingga anak mengaitkan gambar emoji dengan pengalaman mereka yang pernah melihatnya.

Pertemuan 2 (kelompok 3)

Peneliti : [menunjukkan objek matahari dan awan] kalau ini emoji apa yah? Ayo siapa yang tahu?

Anak 3 : Matahari $\mathrm{Bu}$, untuk jemur baju.

Anak 4 : Iya $\mathrm{Bu}$, di cuci dulu terus di jemur kasih kena matahari [di bawah matahari]
Anak 5 : kalau yang putih itu awan $\mathrm{Bu}$, kalau warnanya hitam berarti mau hujan.

Peneliti :Hebat semua, matahari dan awan itu benda-benda yang terlihat di langit. Nah, kalau gambar ini apa yah? [menunjukkan gambar bola]

Beberapa anak: Bola, untuk main bola [sebagian anak langsung berdiri dan berpura-pura menendang]

Peneliti : Wah, sering main bola ya?

Anak 4 : Iya $\mathrm{Bu}$, kemarin main bola dan di sini banyak bola

Dari diskusi kedua dan hasil observasi, anak dapat lebih mudah mengaitkan pengalaman mereka pada gambar mengenai objek yang diberikan. Anak terlihat lebih percaya diri membicarakan pendapat dan ide mereka secara langsung. Disisi lain, saat anak diberikan gambar mengenai emoji wajah mereka terlihat tertarik namun lebih terlihat susah saat memberikan definisi aatu mengaitkan pengalaman mereka dengan emoji wajah tersebut. Contohnya emoji sedih $80^{\circ}$, anak dapat menirukan emoji tersebut namun mengalami kesulitan saat harus menyebutkan definisi atau makna dari emoji tersebut dan mengaitkannya pada pengalaman yang terkait emoji tersebut. Namun, ekspresi yang mereka tampilkan adalah wajah sedih, namun mereka tidak percaya diri dalam mengungkapkan pendapat dan ide mereka dibandingkan dengan emoji objek yang sebelumnya. 
Waode Eti Hardiyanti, Muhammad Ilham, Aris Suziman, Astriyani

PENGGUNAAN EMOJI $\ddot{\theta}$ UNTUK MENINGKATKAN PERILAKU BAIK (WELLBEING) DAN KEMAMPUAN BAHASA ANAK USIA DINI

Early Childhood: Jurnal Pendidikan. Vol. 3 No. 2., November 2019

\section{Pertemuan 3 dan 4}

Pada pertemuan ke- 3 dan 4, mayoritas anak telah mampu menghubungkan emoji dengan pengalaman mereka sehari-hari. Tidak hanya memberikan definisi dari emoji tetapi mereka juga dapat menegosiasikan beberapa makna emoji yang diartikan berbeda-beda seperti pada dialog di bawah ini.

Peneliti : [menunjukkan emoji sakit] nah, kalau emoji ini apa yah?

Anak : sedih $\mathrm{Bu}$, dia sedih.

Anak-anak : menangis $\mathrm{Bu}$, [anak lainnya] sakit $\mathrm{Bu}$, [anak lainnya] marah marah $\mathrm{Bu}$.

Anak : ini sakit $\mathrm{Bu}$ karena panas [emoji menggunakan kompres di dahi]

Peneliti : wah, ada banyak pendapat ya, sedih, menangis, marah, sakit, menurut kalian mana yang paling tepat?

Beberapa anak: sakit itu $\mathrm{Bu}$ karena kalau sakit ditaruh kain disini [menunjuk dahi], [anak lainnya] iya $\mathrm{Bu}$, saya juga begitu sama Mama [Ibunya memberikan kompres]

Anak : iya $\mathrm{Bu}$, kalau sakit minum obat supaya cepat sembuh

Peneliti : wah, ceritanya menarik semua, dan betul sekali kalau sakit itu harus istrirahat dan minum obat. Iyakan?

Anak-anak : Iya Bu...

Diskusi di atas menggambarkan anak berdiskusi dan memberikan pendapat mereka terkait emoji yang dibahas untuk dihubungkan dengan pengalaman sehari-hari. Selain itu, anak mengatasi perbedaan pendapat dengan memberikan klarifikasi dan contoh langsung mengenai definisi emoji. Meskipun kosakata yang ingin diucapkan tidak sepenuhnya diutarakan namun mereka mengantisipasi dengan gerakan yang sesuai, sehingga orang lain dapat mengerti. Anak juga memberikan solusi yang tepat pada situasi yang ada, contohnya, menganjurkan meminum obat bila merasa sakit. Sehingga, diskusi tersebut menjadi lebih bermakna karena anak yang menjadi pusat dari diskusi ini.

Kemampuan Bahasa Anak

Aktivitas yang melibatkan emoji menstimulus anak untuk mengungkapkan gagasan dan pendapat yang dihubungkan dengan pengalaman sehari-hari mereka (Kelly \& Watts, 2015). Media yang sesuai dengan umur anak dan topik dari emoji yang tidak jauh dari pengalaman mereka membuat diskusi lebih bermakna dalam mendengar pendapat anak yang juga meningkatkan kepercayaan diri untuk bersuara.

Aspek-aspek kemampuan berbahasa anak yang ditingkatkan selama kegiatan ini berupa kosakata, kemampuan anak dalam memberikan definisi, solusi dan contoh dari situasi tertentu, dan kepercayaan diri yang meningkat. Untuk peningkatan kosakata, anak mengetahui kosakata baru yang didengar, kemudian 
Waode Eti Hardiyanti, Muhammad Ilham, Aris Suziman , Astriyani

PENGGUNAAN EMOJI $\because$ UNTUK MENINGKATKAN PERILAKU BAIK (WELLBEING) DAN KEMAMPUAN BAHASA ANAK USIA DINI

Early Childhood: Jurnal Pendidikan. Vol. 3 No. 2., November 2019

menggunakan kata dengan ekspresi yang sesuai konteks, contohnya, anak setelah melihat gambar lilin, secara otomatis menghubungkannya dengan pesta ulang tahun, lalu memperagakan meniup lilin.

Kunci utama dari kegiatan ini adalah anak menjadi pusat dari pembelajaran dimana pengalaman, pendapat dan ide mereka sangat didengar dan dihargai. Dengan memiliki rasa percaya diri, anak tanpa ragu terlibat aktif dan termotivasi untuk berbicara (Gallo, Swaney-Stueve, \& Chambers, 2017).

Manfaat lainntya dari kegiatan ini adalah emoji dapat digunakan dalam berbagai kegiatan, selain untuk meningkatkan well-being dan kemampuan bahasa anak. Contohnya, penggunaan emoji sebelum kelas dimulai untuk meningkatkan nilai afeksi antara guru dan murid, dimana anak memilih emoji yang sesuai dengan suasana hati mereka kemudian menentukan jenis sapaan yang akan dilakukan bersama guru (memeluk, berjabat tangan, high-five, atau fist bump), seperti terlihat pada gambar di bawah.

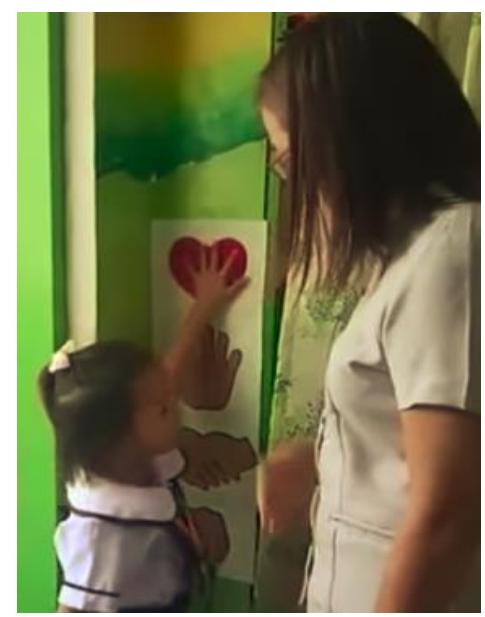

Gambar 4. Anak memilih emoji sebelum masuk ke kelas

Kegiatan menggunakan emoji sebaiknya diteliti sebanyak mungkin dalam sekolah sebab dapat membantu anak yang kesulitan dalam mengungkapkan perasaan dan ekspresi. Untuk itu, emoji seharusnya dimasukkan dalam pembelajaran untuk memudahkan anak dalam mengidentifikasi perasaan dan memudahkan dalam mengungkapkan pendapat mengenai perasaan tersebut sehingga anak dapat berperilaku yang sesuai dengan perasaan yang dirasakan.

Penelitian ini juga dapat diterapkan pada anak berkebutuhan khusus dan anak yang mengalami perlambatan dalam berbicara ataupun mengungkapkan perasaan. Emoji dapat digunakan sebagai media yang membantu anak dapat mengungkapkan perasaan dan untuk memulai suatu percakapan. Ke depannya, produksi media emoji akan sangat menjadi lahan yang potensial, sehingga peluang bisnis pun akan sangat menjanjikan. 
Waode Eti Hardiyanti, Muhammad Ilham, Aris Suziman, Astriyani

PENGGUNAAN EMOJI $\ddot{\theta}$ UNTUK MENINGKATKAN PERILAKU BAIK (WELLBEING) DAN KEMAMPUAN BAHASA ANAK USIA DINI

Early Childhood: Jurnal Pendidikan. Vol. 3 No. 2., November 2019

SIMPULAN

Well-being dan kemampuan bahasa anak secara positif dapat ditingkatkan dengan penggunaan emoji didalam pembelajaran, yang disimpulkan sebagai berikut:

1. Selama empat pertemuan anak selalu menunjukkan ketertarikan dan peningkatan saat mengidentifikasi, mendefinisikan, menjelaskan dan menghubungkan emoji dengan objek dan perasaan yang mereka alami. Anak menceritakan pengalaman seharihari yang berhubungan dengan emoji, sehingga mereka menjadi pusat dari kegiatan belajar dimana pendapat dan ide mereka sangat didengar dan dihargai.

2. Melibatkan dan mendengarkan pendapat anak merupakan indikator penting untuk meningkatkan perilaku baik anak.

3. Media emoji yang berwarna dan menampilkan beragam ekspresi wajah menawarkan pendekatan yang inovatif dan baru untuk meningkatkan perilaku baik anak yang sesuai dengan karakter pendidikan anak usia.

4. Penggunaan media emoji pada anak usia sebaiknya tidak hanya untuk meningkatkan perilaku baik anak tetapi juga dalam pembelajaran yang lainnya, misalnya meningkatkan nilai afeksi anak. Oleh karena itu, penelitian yang mengeksplorasi emoji pada harus ditingkatkan lagi, misalnya bagaimana emoji dapat digunakan pada anak berkebutuhan khusus dan pada pembelajaran di Sekolah Dasar.

\section{UCAPAN TERIMAKASIH}

Dalam menyelesaikan penelitian ini, banyak pihak yang telah membantu sehingga tak lupa kami ucapkan terima kasih kepada Kementerian Riset, Teknologi, dan Pendidikan Tinggi Republik Indonesia, Rektor Universitas Sulawesi Tenggara. 
Waode Eti Hardiyanti, Muhammad Ilham, Aris Suziman, Astriyani

PENGGUNAAN EMOJI $\ddot{\theta}$ UNTUK MENINGKATKAN PERILAKU BAIK (WELLBEING) DAN KEMAMPUAN BAHASA ANAK USIA DINI

Early Childhood: Jurnal Pendidikan. Vol. 3 No. 2., November 2019

\section{DAFTAR PUSTAKA}

Bawono, Y. (2017). Kemampuan berbahasa pada anak prasekolah : Sebuah kajian pustaka. Prosiding Temu Ilmiah X Ikatan Psikologi Perkembangan Indonesia, 116125.

Delfita, R. (2009). Meningkatkan Kemampuan Berbahasa Anak Melalui Permainan Gambar Dalam Bak Pasir Di Taman Kanak-Kanak Bina Anaprasa Mekar Sari Padang. Jurnal Pesona Paud, Vol I(No.I), 1-10.

Fane, J. (2017). Using emoji as a tool to support child wellbeing from a strengths-based approach. Learning Communities: International Journal of Learning in Social Contexts, 21, 96-107. https://doi.org/10.18793/lcj2017.2 1.08

Fane, J., MacDougall, C., Redmond, G., Jovanovic, J., \& Ward, P. (2016). Young children's health and wellbeing across the transition to school: A critical interpretive synthesis. Children Australia, 41(2), 126-140. https://doi.org/10.1017/cha.2016.4

Gallo, K. E., Swaney-Stueve, M., \& Chambers, D. H. (2017). A focus group approach to understanding food-related emotions with children using words and emojis. Journal of Sensory Studies, 32(3), $1-10$. https://doi.org/10.1111/joss.12264

Kelly, R., \& Watts, L. (2015). Characterising the Inventive Appropriation of Emoji as Relationally Meaningful in Mediated Close Personal

\author{
Relationships. Experiences of \\ Technology Appropriation: \\ Unanticipated Users, Usage, \\ Circumstances, and Design.
}

Kementerian Pendidikan dan Kebudayaan Indonesia. (2014). Kurikulum 2013 pendidikan anak usia dini

Novak, P. K., Smailović, J., Sluban, B., \& Mozetič, I. (2015). Sentiment of emojis. PLoS ONE, 10(12), 122.

https://doi.org/10.1371/journal.po ne.0144296

Suwanti, T. S., Akmal., \& Sodiq, J. (2016). IbM bagi tutor PAUD anak Bangsa VI Kelurahan Tandang Semarang. Jurnal Pengabdian Kepada Masyarakat, VII, (2).

UNICEF. (2013). Child Well-being in Rich Countires: A comparative overview. In U. O. o. Research (Ed.). 